\title{
Pemanfaatan Irigasi Kecamatan Liang Anggang Sebagai Objek Wisata Pemandian
}

\author{
Wanda Aprilla \\ Program Studi Pendidikan IPS, FKIP Universitas Lambung \\ Mangkurat \\ 1810128220022@mhs.ulm.ac.id
}

\begin{abstract}
ABSTRAK
Tujuan ditulisnya artikel ini untuk mendeskripsikan pemanfaatan irigasi Kecamatan Liang Anggang sebagi objek wisata pemandian serta potensi-potensi yang didapat terdapat pada wisata pemandian tersebut. Pada umumnya irigasi hanyalah suatu upaya untuk pengelolaan dan penyediaan air untuk menunjang kebutuhan pertanian. Namun, setelah kejadian banjir tahun ini yang melanda hampir seluruh daerah Kalimantan Selatan termasuk kecamatan Liang Anggang maka kedalaman air di seluruh aliran sungai sampai irigasipun menjadi lebih meningkat dari sebelumnya, dan setelah keadaan mulai kembali normal maka masyarakat memanfaatkan air irigasi sebagai tempat pemandian. Sehingga saat ini irigasi di kecamatan Liang Anggang menjadi dua fungsi yaitu sebagai aliran air yang dimanfaatkan sebagai pengeloaan pertanian dan juga objek wisata pemandian bagi masyarakat sekitar. Objek wisata pemandian ini terletak di di Jalan Jurusan Pelaihari Jembatan Dua RT.03 RW.01, Kelurahan Landasan Ulin Selatan, Kecamatan Liang Anggang. Rata-rata pengunjung kebanyakanya warga daerah Liang Anggang dan sekitarnya dan terdapat beberapa potensi yang dapat dimanfaatkan dengan adanya wisata peamandian ini. Demikian, potensi-potensi dari objek wisata ini antara lain menjadi tempat rekreasi, meningkatkan ekonomi masyarat dan juga dapat dijadikan sumber belajar IPS.
\end{abstract}

Kata kunci : Irigasi, objek wisata pemandian, rekreasi, kegiatan ekonomi, sumber belajar IPS

\section{PENDAHULUAN}

Beberapa waktu yang lalu hampir seluruh wilayah Kalimantan Selatan terendam banjir akibat curah hujan yang deras, mengakibatkan banyak DAS atau irigasi yang airnya mengalami kedalaman yang meningkat. Melihat keadaan air irigasi yang cukup dalam membuat masyarakat disekitar irigasi memanfaatkan hal tersebut sebagai pemandian bagi anak-anak dan remaja. Dengan perkembangan sosial media saat ini, para masyarakat menyebarkan kegiatan anak-anak dan remaja yang memanfaatkan irigasi sebagai pemandian di media sosial masing-masing yang menyebabkan banyaknya masyarakat daerah lain ikut datang dan merasakan pemandian tersebut. Sehingga saat ini irigasi tidak lagi dimanfaatkan 
hanya sebagai usaha penyediaan, pengaturan, dan pembuangan air irigasi untuk menunjang pertanian tetapi juga bisa dijadikan objek wisata pemandian bagi masyarakat sekitar irigasi.

Berdasarkan kenyataan dilapangan ternyata terdapat banyak potensi yang di dapat dari Irigasi di Kecamatan Liang Anggang tersebut yang dimanfaatkan masyarakan bahkan juga peserta didik sebagai fasilitas daerah yang dapat di nikmati. Berdasarkan pembahasan mengenai irigasi kecamatan Liang Anggang sebagai objek wisata pemandian ini cukup menarik untuk dikaji guna melihat bagaimana pemanfaatan irigasi sebagai objek wisata pemandian dan potensi yang ada dari adanya objek wisata pemandian ini sehingga masyarakat dapat memanfaatkan potensi yang bermanfaat sebagai pemenuh kebutuhan tersier dalam kehidupannya.

\section{PEMBAHASAN}

Berdasarkan pasal 1 ayat 3 menjelaskan bahwa Irigasi adalah suatu upaya untuk pengelolaan dan penyediaan air untuk menunjang kebutuhan pertanian. Jenisnya seperti irigasi permukaan, irigasi rawa, irigasi air dasar tanah, irigasi pompa, serta irigasi tambak untuk menunjang produktivitas usaha tani guna tingkatkan penciptaan pertanian dalam rangka ketahanan pangan nasional serta kesejahteraan warga, spesialnya petani, yang diwujudkan lewat keberlanjutan sistem irigasi. Menurut Linsley dan Franzini (1992) irigasi adalah pengaliran air pada tanah untuk membantu pengaturan ketersedian air dikarenakan curah hujan yang tidak cukup sehingga air bisa tersedia secara optimal bagi pertumbuhan tanaman (Setiadi, D., \& Muhaemin, M. N. A. 2018).

Objek wisata merupakan Objek yang berarti wujud serta Wisata merupakan sarana yang berhubungan dengan wujud tersebut, yang bisa menarik atensi wisatawan ataupun turis buat tiba ke tempat objek tersebut (M.A Sianapar, Benvri. 2015). Menurut UU Republik Indonesia Nomor 10 Tahun 2009 menjelaskan tentang kegiatan wisata adalah kegiatan kunjungan manusia baik secara orang ataupun secara kelompok untuk mengarah tempat tertentu bertujuan tamasya, mengeksplorasi dari wilayah wisata, dalam menaikkan kemampuan diri serta yang lain baik dalam waktu yang pendek maupun dalam jangka waktu yang pendek dalam aktivitas wisata tersebut. (Abbas, E. W., Hidayat Putra, M. A., \& Noor Handy, M. R. 2019).

Pada saat ini objek wisata sangat di butuhkan untuk menjadi tempat pariwisata sehingga banyak tempat yang awal mulanya tidak ditujukan selaku objek wisata 
dijadikan objek wisata. Salah satunya adalah irigasi yang bertempat di Jalan Jurusan Pelaihari Jembatan Dua RT.03 RW.01, Kelurahan Landasan Ulin Selatan, Kecamatan Liang Anggang. Wisata pemandian Liang Anggang ini merupakan salah satu objek wisata yang menarik dan gratis, selain itu wisata ini tidak hanya menyajikan tempat pemandian saja tetapi juga pemandangan yang cukup indah untuk dilihat sembari melepas penat dari hiruk pikuk perkotaan. Pengunjung yang berdatangan kebanyakanya warga daerah Liang Anggang dan sekitarnya dan biasanya memadati tempat wisata ini dimulai dari Pukul 16.00 hingga 18.00 WITA.

Pada saat ini wisata pemandian Liang Anggang mengalami penurunan pengunjung dikarenakan adanya penutupan oleh pihak Kapolsek Banjarbaru Barat dan Danramil Liang Anggang untuk pencegahan kluster kedua covid-19 di Banjarbaru. Sehingga saat ini, wisata pemandian Liang Anggang ini tidak seramai diawal karena kabar mengenai penutupan sudah tersebar, akan tetapi anak-anak dan remaja disana masih tetap diperbolehkan untuk menggunakan irigasi ini sebagai tempat pemandian. Berdasarkan pemanfaatan irigasi sebagai objek wisata ini menimbulkan beberapa potensi yang bermanfaat bagi masyarakat bahkan dalam pendidikan Adapun beberapa potensi-potensi dari pemanfaatan irigasi sebagai objek wisata pemandian Liang Anggang antara lain :

\section{Tempat Rekreasi}

Menurut Kamus Besar Bahasa Indonesia (KBBI), arti kata rekreasi adalah penyegaran kembali badan dan pikiran. Rekreasi ini merupakan suatu terapi kesehatan dengan menghilangkan beban pikiran saat bekerja lelah tidak hanya perlu fisik yang sehat tetapi kesehatan mental juga harus seimbang. Salah satu lingkungan alam yang dapat menjadi tempat rekreasi adalah wisata pemandian Liang Anggang ini, karena tempat ini menyajikan tidak hanya pemandian alternatif dari aliran air irigasi tetapi juga pemandangan yang indah sehingga cocok untuk menjadi penyegar pikiran setelah lelah menjalankan rutinitas sehari-hari.

2. Meningkatkan Ekonomi Masyarakat

Kegiatan berdagang atau jual beli termasuk dalam kegiatan ekonomi. Kegiatan ekonomi merupakan aktivitas ataupun usaha manusia untuk memenuhi kebutuhan hidupnya (Maulidiyah, M., Subiyakto, B., \& 
Hasanah, M. 2020). Perdagangan adalah kegiatan atau proses jual beli dan tawar-menawar antara seorang penjual dan pembeli untuk saling memenuhi kebutuhan (W.J.S Poerwadarminta. 1976). Dengan adanya wisata pemandian Liang Anggang ini yang cukup ramai di kunjungi oleh masyarakat sehingga banyak orang bejualan dari penjual pentol, penjual minuman es, terima jasa sewa pelampung dan warung kecil. Sehingga mendapatkan keuntungan dari memanfaatkan wisata pemandian Liang Anggang tersebut untuk berniaga dalam setiap hari nya ini termasuk meningkatkan ekonomi masyarakat.

3. Sumber Belajar IPS

Lingkungan dapat dimanfaatkan sebagai sumber belajar yang dapat diterapkan pada mata IPS (Ajidayanti, A., \& Abbas, E. W. 2019). Inovasiinovasi dalam pendidikan IPS sudah dilakukan lewat eksplorasi sumber belajar IPS dengan menggunakan kemampuan lokal atau lingkungan sekitar (Subiyakto, B., \& Mutiani, M. 2019). Sebagian aspek yang pengaruhi keefektifan pemanfaatan lingkungan sekitar oleh pendidik selaku sumber belajar ialah keahlian pendidik, kemampuan pendidik dalam mengoptimalkan lingkungan yang hendak digunakan dalam proses pendidikan (Yuniarti, D., Subiyakto, B., \& Putra, M. A. H. .2020).

Oleh sebab itu, wisata pemandian Liang Anggang dapat dijadikan sumber belajar karena objek wisata ini berada di lingkungan sekitar peserta didik sehingga peserta didik mampu mempelajari mengenai tema lingkungan seperti yang terkandung dalam pembelajaran IPS mulai dari penjagaan alam atau lingkungan, melihat berbagai macam pola interaksi, gambaran sistem perdagangan yang ada disekitar peserta didik itu sendiri. Dengan demikian, tempat ini bukan hanya sebagai taman bermain melainkan juga sebagai sumber belajar dengan melihat berbagai macam yang dapat dikaitkan dengan materi pembelajaran. 


\section{SIMPULAN}

Irigasi adalah suatu upaya untuk pengelolaan dan penyediaan air untuk menunjang kebutuhan pertanian. Irigasi juga dapat dimanfaatkan sebagai objek wisata pemandian alternatif dan bebas biaya. Irigasi yang dijadikan objek wisata pemandian tersebut berada di Jalan Jurusan Pelaihari Jembatan Dua RT.03 RW.01, Kelurahan Landasan Ulin Selatan, Kecamatan Liang Anggang. Pemanfaatan irigasi sebagai objek wisata pemandian di Liang Anggang mampu memberikan beberapa dampak positif bagi masyarakat dan juga dalam pembelajaran yaitu berpotensi sebagai

tempat rekreasi, meningkatkan ekonomi masyarakat, bahkan dapat dijadikan sebagai sumber belajar dalam pembelajaran IPS. 


\section{DAFTAR PUSTAKA}

Agusni, R. F. (2017). Perbandingan Sosial Ekonomi Pedagang kaki Lima Sebelum dan Sesudah Pembangunan Taman Kota di Kota pariaman. Jurnal Spasial: Penelitian, Terapan Ilmu Geografi, dan Pendidikan Geografi, 3(1), 131100.

Ajidayanti, A., \& Abbas, E. W. (2019). Utilization of Tourism Bekantan Mascot as a Learning Resource On Social Studies. The Innovation of Social Studies Journal, 1(1), 78-86

Abbas, E. W., Hidayat Putra, M. A., \& Noor Handy, M. R. (2019). Laporan Penelitian: Pemanfaatan Ekowisata Sungai Martapura Kota Banjarmasin Sebagai Sumber Belajar IPS.

M.A Sianapar, Benvri. 2015. Upaya Pengembangan Pantai Pasir Putih Pangkodian Sebagai Objek Wisata Di Kabupaten Toba Samosir. Medan.

Maulidiyah, M., Subiyakto, B., \& Hasanah, M. (2020). Economic Activities in The Kebun Rambutan Rakyat Sungai Lulut as a Learning Resource on Social Studies. The Kalimantan Social Studies Journal, 1(2), 175-183.

Rekreasi (Def.1) (n.d) Dalam Kamus Besar Bahasa Indonesia (KBBI) Online. Diakses melalui https://kbbi.web.id/rekreasi. 12 Maret 2021

Setiadi, D., \& Muhaemin, M. N. A. (2018). Penerapan Internet Of Things (IoT) Pada Sistem Monitoring Irigasi (Smart Irigasi). Infotronik: Jurnal Teknologi Informasi dan Elektronika, 3(2), 95-102.

Subiyakto, B., \& Mutiani, M. (2019). Internalisasi nilai pendidikan melalui aktivitas masyarakat sebagai sumber belajar ilmu pengetahuan sosial. Khazanah: Jurnal Studi Islam dan Humaniora, 17(1), 137-166

W.J.S Poerwadarminta (1976) Kamus Umum Bahasa Indonesia. Jakarta :Balai Pustaka.

Yuniarti, D., Subiyakto, B., \& Putra, M. A. H. (2020). Economic Activities in Kuin Floating Market as a Learning Resource on Social Studies. The Kalimantan Social Studies Journal, 1(2), 130-140. 